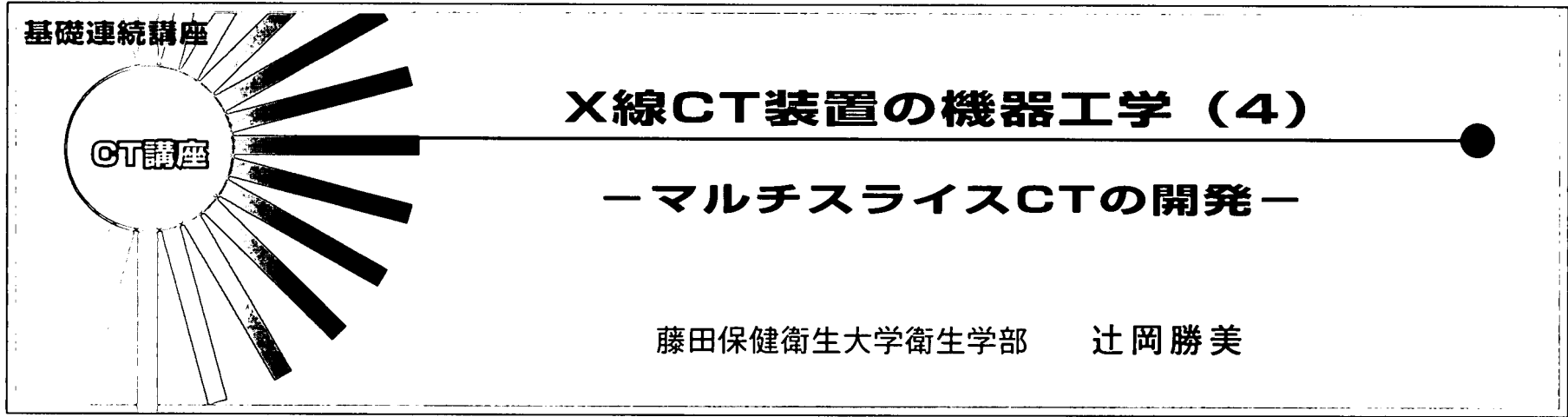

最近のCT研究の中心といえばマルチスライスCTで ある．従来のシングルスライスCTによるへリカルス キャンが開発されてから約10年, ヘリカルスキャンが ボリュームCTデータの第一歩で，現在のマルチスラ イスヘリカルスキャンがその第二歩である。将来的に は面検出器による連続ボリュームデータ収集の時代も 遠くない，従来の二次元画像装置であったCTが三次 元画像装置を超えて四次元画像装置となるのである.

\section{1. シングルスライスCTからマルチスライスCTへ}

従来のノンヘリカルスキャンからヘリカルスキャン へ，それは画像診断において画期的な進歩であった. 従来の二次元的な画像診断から三次元的な画像診断, 検查時間の短縮による造影効果の増大，1回の呼吸停 止でのスキャン，等々，その臨床的有用性は一時MRI の登場に押されぎみであったCTを復活させた感じで あった.そして，その熱の冷めないうちに開発された のがマルチスライスCTである、マルチスライスCTは 棈造的にはCT装置の検出器を体軸方向に複数設犆し ただけという感じもする。しかし，そこには多くの革
新的技術が存在する。また，マルチスライスCTによ るへリカルスキャンにはシングルスライスCTによる よりも多くの臨床的な有用性も存在する。本章では, マルチスライスCTの構造的な特性と画像再椿成につ いて解説する。

\section{2. 多列検出器}

従来のシングルスライスCTでは数百の検出器が1 列に並んでいた。これにより1回転のデータ収集で 1 枚の画像再構成が行われた。ママルチスライスCTでは 検出器列が複数になった。ここでは従来のスライス面 (XY面)方向をチャンネル方向, 体軸方向に並んだ列 をエレメント方向と呼ぶ.マルチスライスCTにおけ る検出器の構造はメーカによって異なっており, 均等 に配列したタイプ，周辺に対して中央部分を細かくし たタイプ，また，検出器の配列とその直前につけた遮 蔽板で検出器幅を決定するタイプと各種が開発されて いる(Fig. 1). マルチスライスCTと言っても検出器の 列数がスライス数を決定するものではなく，データ収 集システム (DAS : data acquisition system)の数で再輩

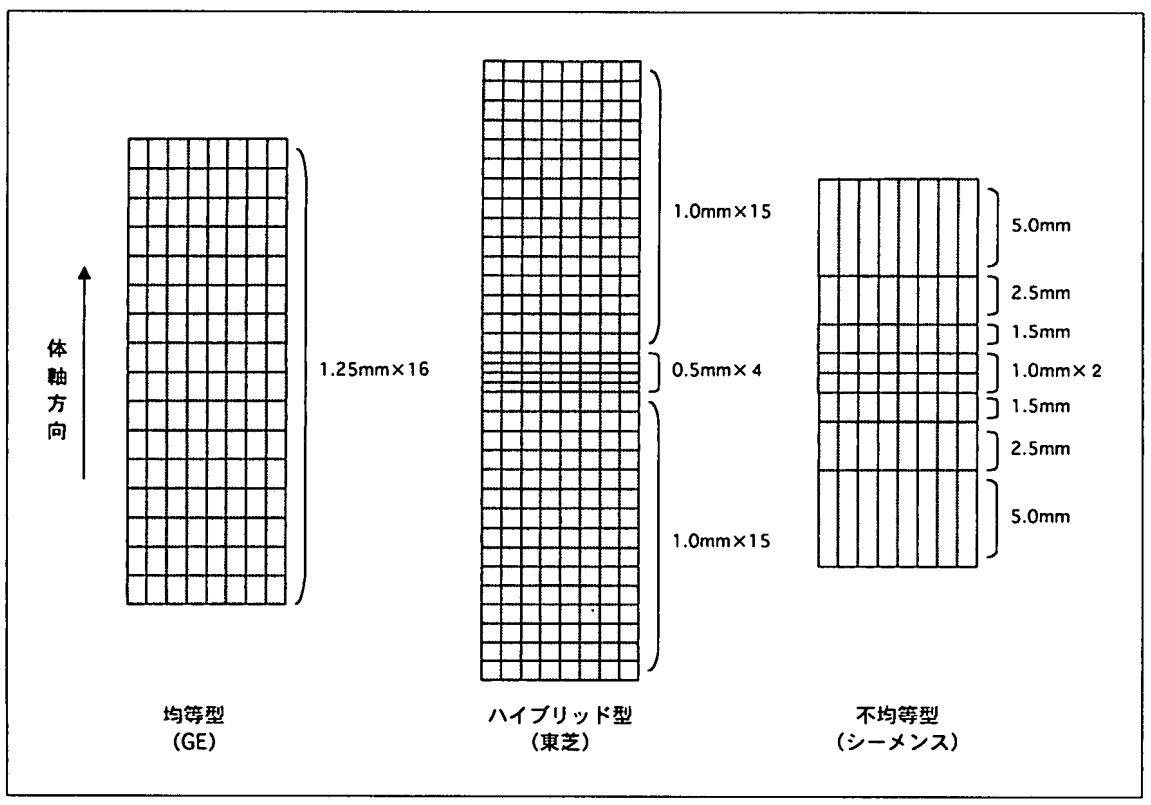

Fig. 14 DASマルチスライスCTの検出器 4 DASマルチスライスCTでは各種の 検出器形式がある. スライス枚数は DASの数で決定される. 


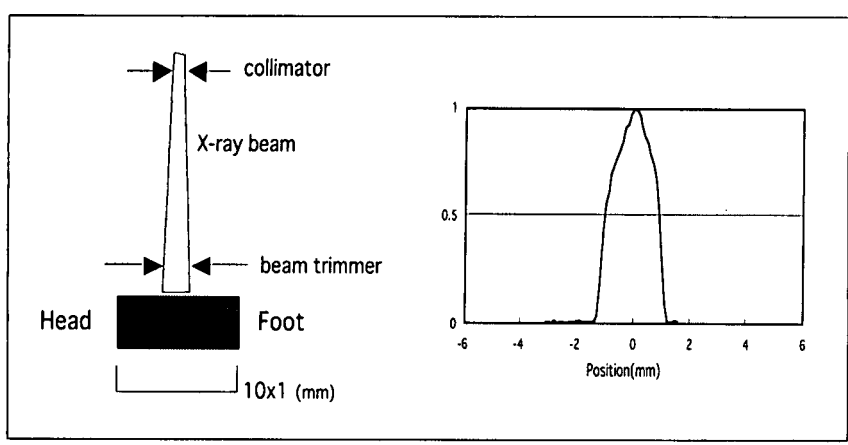

Fig. 2 シングルスライスCT(ビームトリマ有)の検出器の構 造とスライス感度プロフィール シングルスライスCTでは薄いスライス厚の実現に多 くの苦労があった. $2 \mathrm{~mm}$ 以下のスライス厚ではビー ムトリマを利用してスライス形状の整形が行われて いた。

成画像数が決定する．現在普及しているマルチスライ スCTでは 4 DAS, 近年 8 DAS, 16DASのものも開発 され，それぞれに異なった特性を有する。このことか らマルチスライスCTでは 4 DAS， 8 DASとDAS数を つけて呼ぶことが望まれる. 特に, 研究発表, 論文等 での呼び名は気をつけるべきと思うがいかがであろう か.

マルチスライスCTの検出器について, 特筆すべき は体軸方向のスライス感度プロフィールの形状であ る. 後述するIsotoropic dataの収集にはこの特性が有 効となる. Fig. 2に従来のシングルスライスCTの検出 器構造とそれによるスライス感度プロフィールを示 す．従来のシングルスライスCTではX線管に取り付け られたコリメータによりX線ビームは薄い扇状に制限 される. 被写体を透過したX線ビームは検出器に到達 する. $5 \mathrm{~mm}, 10 \mathrm{~mm}$ の比較的厚いスライス厚ならば これでよいのであるが, $2 \mathrm{~mm}$ 以下の薄いスライス厚 では検出器の直前に設置されたビームトリマでX線ビ 一ムの整形が行われる。これにより十分に薄いスライ ス厚が実現できる。しかし，このような場合，被写体 には照射したが, 検出器には到達しないX線が存在す ることになる. 被曝の問題が発生する.Fig. 3 に 4 DASマルチスライスCTの検出器構造と各スライス感 度プロフィールを示す.マルチスライスCTではビー ムトリマを設置することなく良好な薄いスライス厚が 実現できる。

\section{3. 画像再構成}

マルチスライスCTでヘリカルスキャンを行った場 合，その投影データはシングルスライスCTによるへ リカルスキャンに比べて複雑な螺旋軌道を描く。ここ でも前回と同様に展開図を用いれば容易に理解でき る. Fig. 4 に DASマルチスライスCTでヘリカルピッ

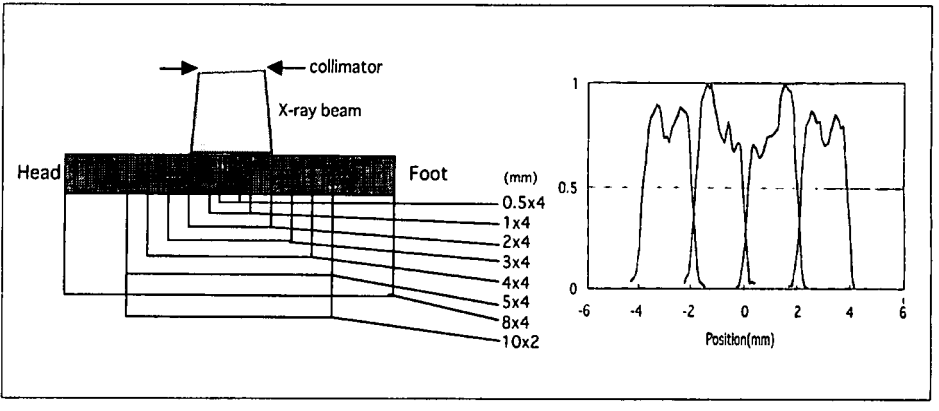

Fig. 3 マルチスライスCT(ハイブリッド型)の検出器の構造 とスライス感度プロフィール

マルチスライスCTではビームトリマなどを用いるこ となく薄いスライス厚が実現できる。そのスライス 感度プロフィールは良好である. スライス感度プロ フィールの上部の変形は検出器の隔壁の影響である が,画像上では問題とはならない.

チを各種変化させたときの展開図を示す。ここで，マ ルチスライスCTのヘリカルスキャンにおけるへリカ ルピッチとは一つのスライ厚に対するX線管 1 回転の 寝台移動距離をいう．シングルスライスCTによるへ リカルスキャンではヘリカルピッチは自由に選択で き，画像再構成される奉効スライス厚はへリカルピッ チに比例して増加した. マルチスライスCTでは基本 的に180度補間が使われているが，ヘリカルピッチに より投影データの分布は均一であったり, 不均一であ ったり，複雑に変化する。ここで目的位置の画像再構 成を考えた場合, 投影データの補間は存在する投影デ 一タに依存して実行される. 特徽的なのはへリカルピ ッチが4のとき, 実データと対向データが重複してし まい，180度補間ではあるが，実データしか利用され ない.このことから, ヘリカルピッチ4では他に比べ て㥶効スライス厚は厚くなる(Fig. 5)。画像ノイズに ついていえば, ヘリカルピッチ4では画像ノイズが低 下する (Fig. 6).

シングルスライスCTによるヘリカルスキャンに比 ベ，マルチスライスCTによるへリカルスキャンでは 投影データが非常に高密度になる。これを利用して行 われるのが軸フィルタである (Fig. 7)。実際には不均 等に分布した投影データについてリサンプリングによ り均等分布にした後，フィルタリングが行われる， Z 軸フィルタによりスキャン後であってもスライス感度 プロフィール，実効スライス愿の変更が自由に行え る.

シングルスライスCTでは画像再構成は二次元的な 考えでのみ行われてきた。 これは，X線ビームの形状 が扇状であり，体軸方向で見れば拡がりのない形状で あったからである．現在普及している4DASのマルチ スライスCTでは体軸方向に若干の拡がりがあるもの の, 実際的な影響がないことから従来の画像再構成が 
1

マルチスライスヘリカルスキャン

ヘリカルピッチ $=3$

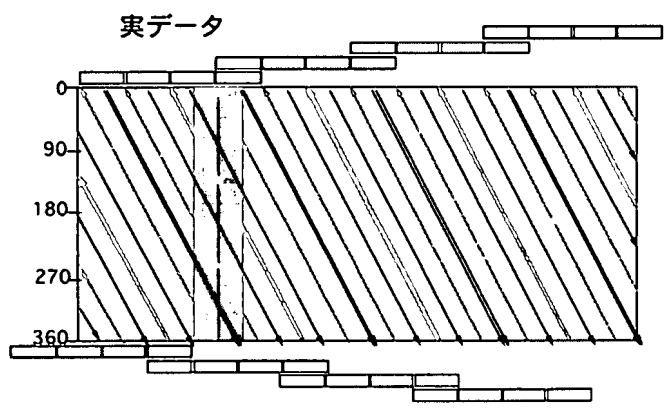

3

マルチスライスヘリカルスキャン

ヘリカルピッチ $=4$

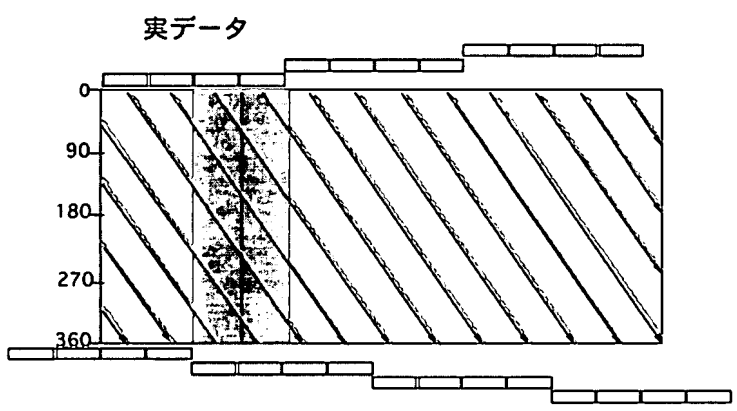

5

マルチスライスヘリカルスキャン

ヘリカルピッチ $=5$

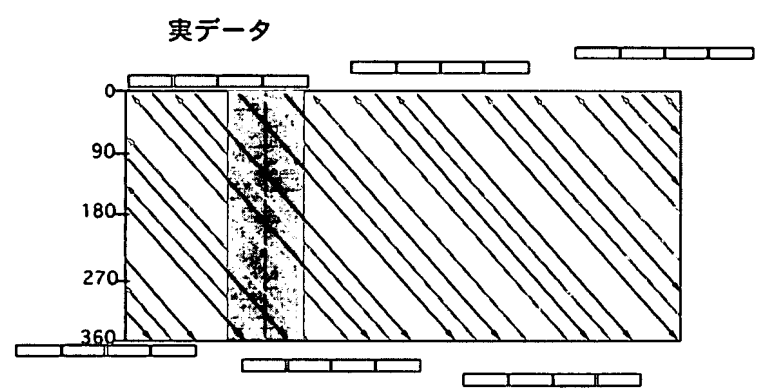

7 マルチスライスヘリカルスキャン

ヘリカルピッチ $=6$

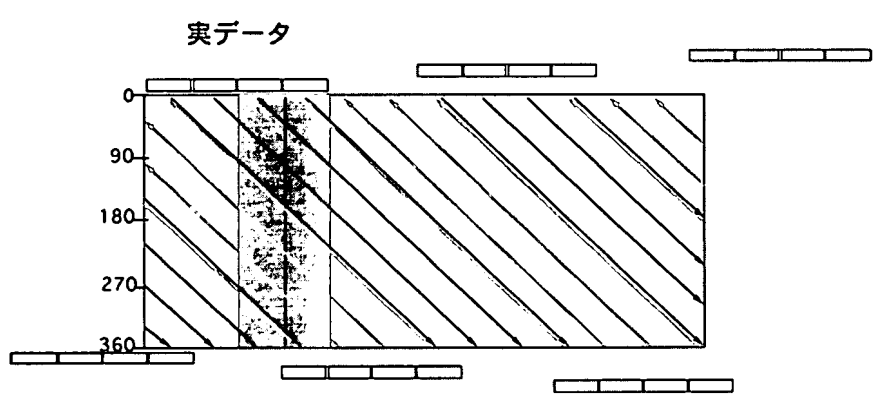

2

マルチスライスヘリカルスキャン

ヘリカルピッチ $=3.5$

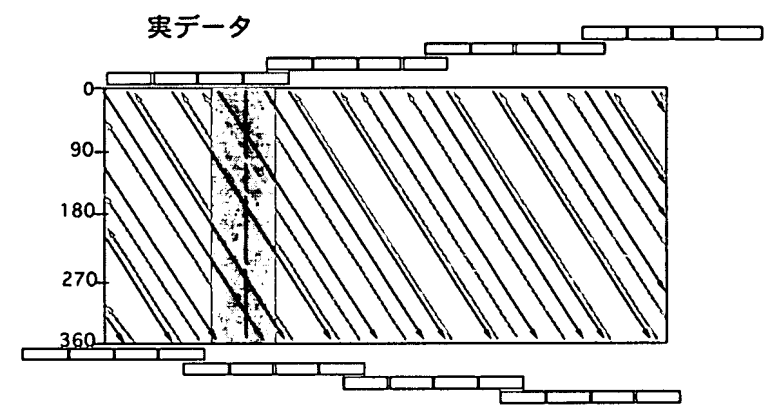

4

マルチスライスヘリカルスキャン

ヘリカルピッチ $=4.5$

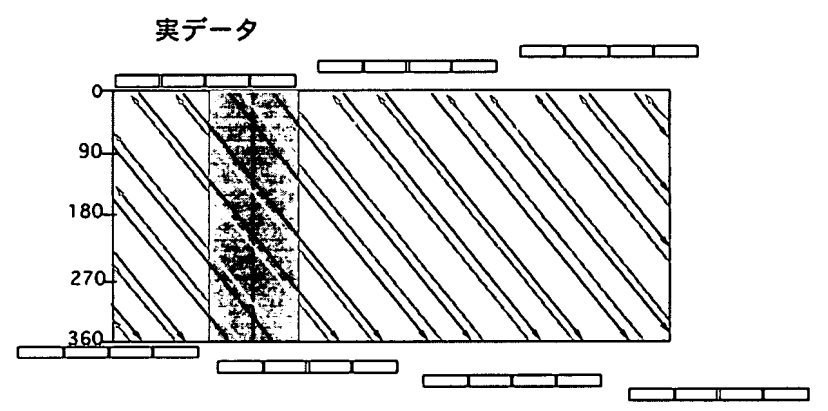

6

マルチスライスヘリカルスキャン

ヘリカルピッチ $=5.5$

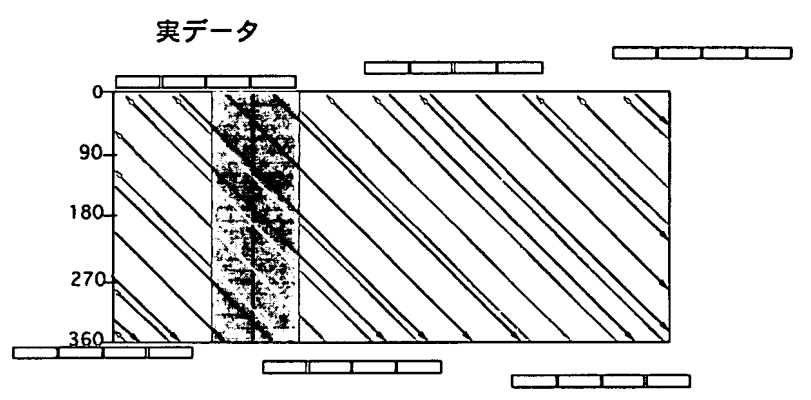

Fig. 44 DASマルチスライスにおける展開図

マルチスライスCTでは投影データの分布密度が高い。また,投影データの分布はヘリカルピッチ $3 ， 4 ， 6$ では均等で あるが、それ以外では不均等となる。 


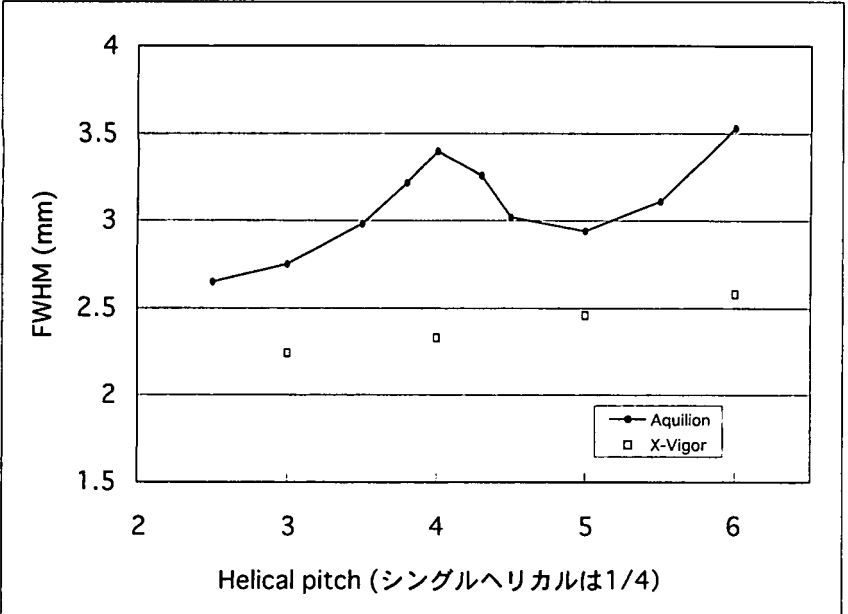

Fig. 5 4DASマルチスライスCTにおけるへリカルピッチと 実効スライス厚の関係

シングルスライスCTによるヘリカルスキャンではへ リカルピッチと比例して実効スライス厚は厚くなっ た.それに対し，4DASマルチスライスCTによるへ リカルスキャンではヘリカルピッチ 4 付近でスライ ス厚の特異的な変化が見られた。 ただし,これはZ軸 フィルタを 2 点補間としたときの結果である.

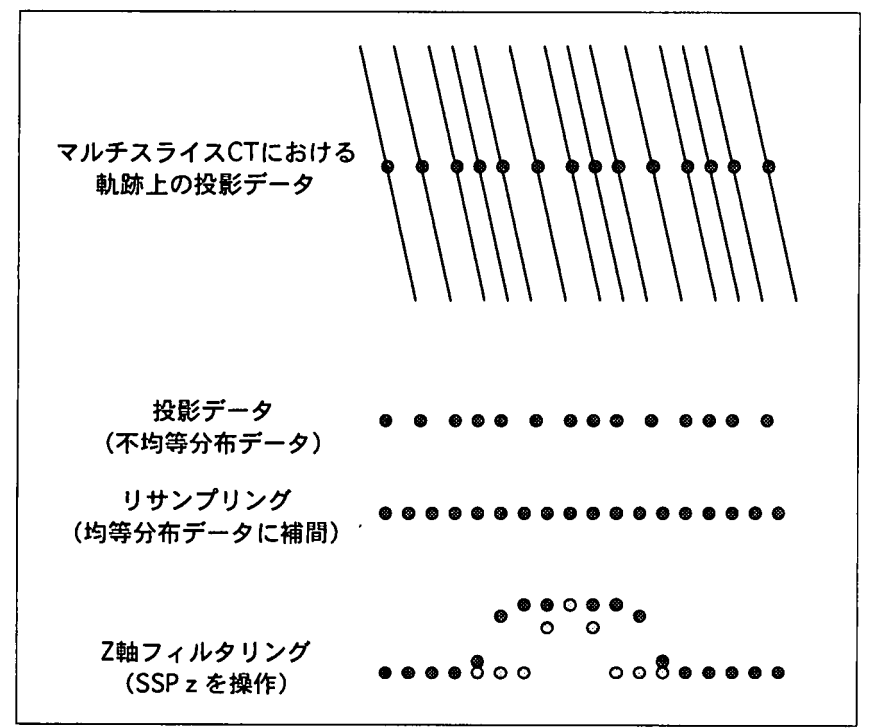

Fig. 7 マルチスライスCTにおけるZ軸フィルタ マルチスライスCTでは投影データの空間的密度が高 いためZ軸についてのフィルタリングが行われる.こ れにより、スキャン後であってもスライス感度プロフ ィールや画像ノイズを調整することができる.

使用されている(Fig. 8)。これが8 DAS，16DASとい ったマルチスライスCTとなると体軸方向に広がりを 持ったコーンビームとして画像再構成を考える必要が ある. 従来の二次元的な画像再構成ではアーチファク トの発生を招くことになる(Fig. 9)。これは，マルチ スライスCTのスライス数が増加し, 検出器の端の列 でスライス厚が薄くなることにより顕著になる。この 現象を低減する目的で利用される再構成法がよく知ら れているfeldkamp法である(Fig. 10)。いわゆる三次元 逆投影法である。ただし，feldkamp法は非へリカルス

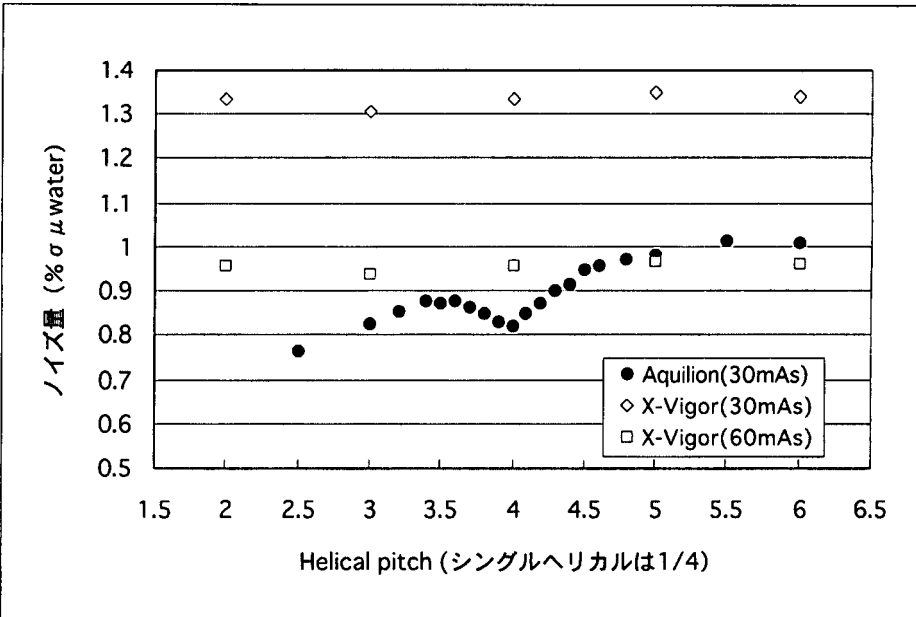

Fig. 6 4DASマルチスライスCTにおけるヘリカルピッチと 実効スライス厚の関係

シングルスライスCTによるへリカルスキャンではへ リカルピッチが変化しても画像ノイズの変化はなか った. それに対し，4 DASマルチスライスCTによる ヘリカルスキャンではヘリカルピッチ 4 付近で画像 ノイズの特異的な変化が見られた。 ただし,これはZ 軸フィルタを 2 点補間としたときの結果である.

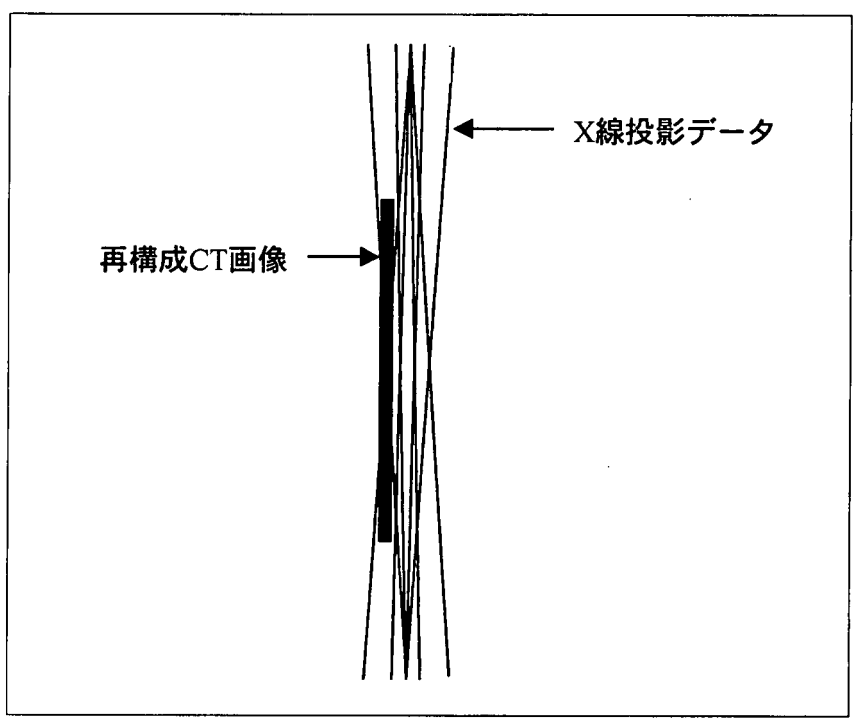

Fig. 8 従来の 4 DAS小コーン角における画像再構成法 マルチスライスCTでも 4DAS程度でコーン角が小さ ければ従来の二次元的な画像再構成が利用できる.

キャンで行われるものであり，実際のマルチスライス CTによるへリカルスキャンでは, feldkamp法を応用 した手法が採用される，feldkamp法によればコーン角 が広くなってもアーチファクトのない画像が得られ る. しかし，その計算量は通常の画像再構成の場合に 比べ膨大であり，実用化には若干の障害もある。 feldkamp法とは別な万法にASSR (advanced single slice rebinning) と呼ばれる方法がある (Fig. 11)。これは, 従来の二次元画像再構成を採用しながら，コーン角の 影響を減少しょうというものである。しかし，この方 


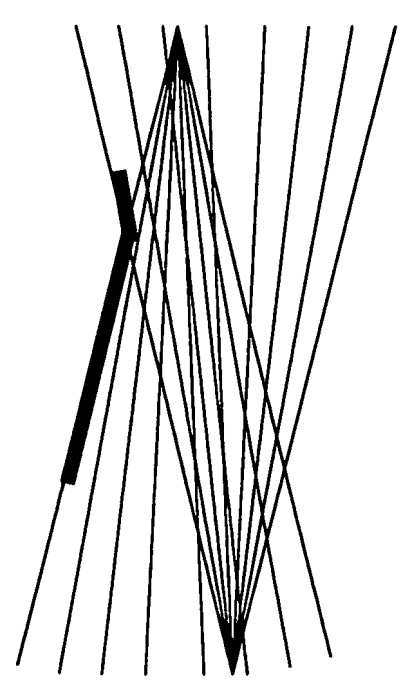

Fig. 9 多数DAS大コーン角では従来再構成が利用できない マルチスライスCTのDAS数が増加し，コーン角が增 加した場合,従来の画像再構成はアーチファクト発生 のために利用できない.

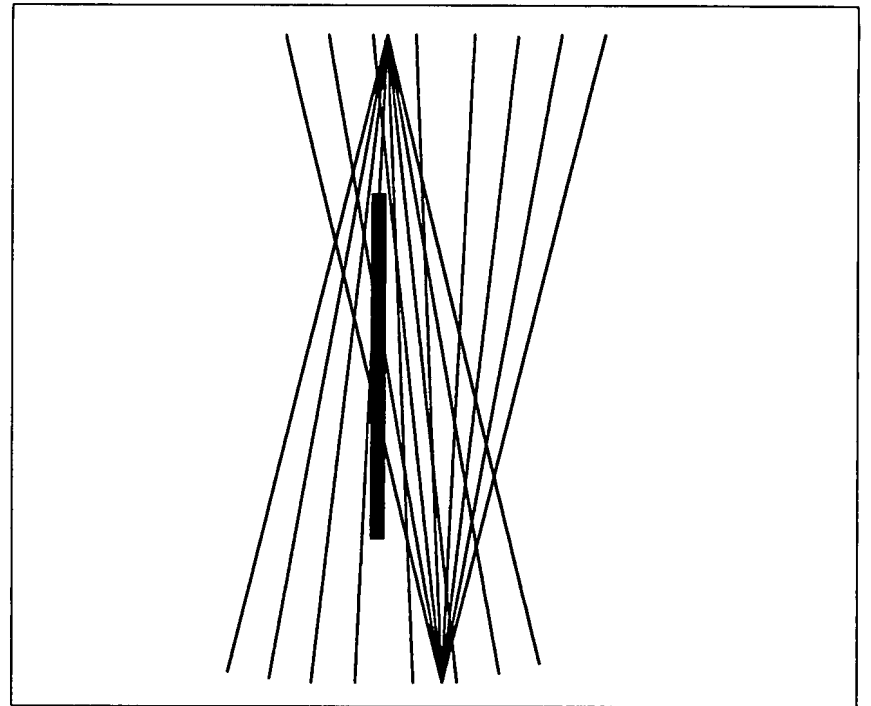

Fig. 10 マルチスライスCTのヘリカルスキャン時の Feldkamp法

Feldkamp法によればコーン角が広くてもアーチファ クトの発生のない再構成画像を得ることができる。

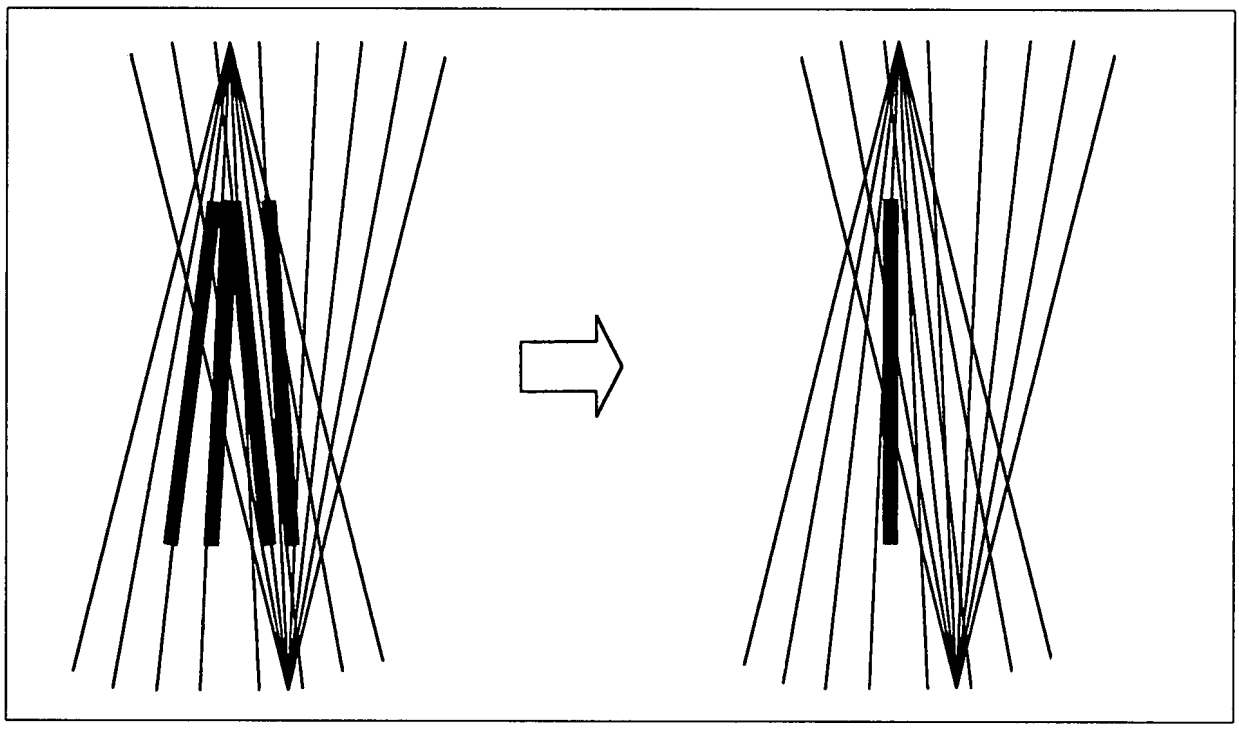

Fig. 11 マルチスライスCTのヘリカル スキャン時のASSR法 ASSR法は計算速度の速さで 有利であるが，アーチファク 卜を完全には消失することは できない。

法ではコーン角の影響を原理的に解決するものではな いことから, feldkamp法に比ベアーチファクトの低減 効果は少ない.マルチスライスの多DAS化が進んでい った場合，このような技術革新が重要な要素となる.

\section{4. マルチスライスCTの矂床的効果}

4 DASマルチスライスCTの登場により，多くの臨 床的効果が報告された。 4DASマルチスライスCTは, 従来のシングルスライスCTにおける 1 列の検出器を 体軸方向に四つに分割したと考えれば，良好な体軸方 向の空間分解能の実現が可能となる。 また, 従来のシ ングルスライスCTにおける 1 列の検出器を四つ体軸 方向に並べたと考えれば，スキャン時間の短縮が可能 となる。ここでは，良好な体軸方向への空間分解能に より可能となる「isotropic resolution」「スキャン時間 の短縮」について述べる.

\section{4-1 isotropic resolution}

マルチスライスCTの登場で臨床上, 最も注目され るものにisotropic resolutionがある. 従来のCTではス ライス面方向 $(X Y$ 方向)の空間分解能に比べて，体軸 方向(Z軸方向)の空間分解能が十分でなかった。 マル チスライスCTの登場により体軸方向の空間分解能を スライス面方向と同等にすることが可能となった。ま た，そのデータの収集も容易となった。このことは MPR表示，三次元表示などを行った場合，どの方向 から見ても同等の空間分解能を実現することとなった (Fig. 12，13)。このことは, 従来の「CTは軸位断」と 

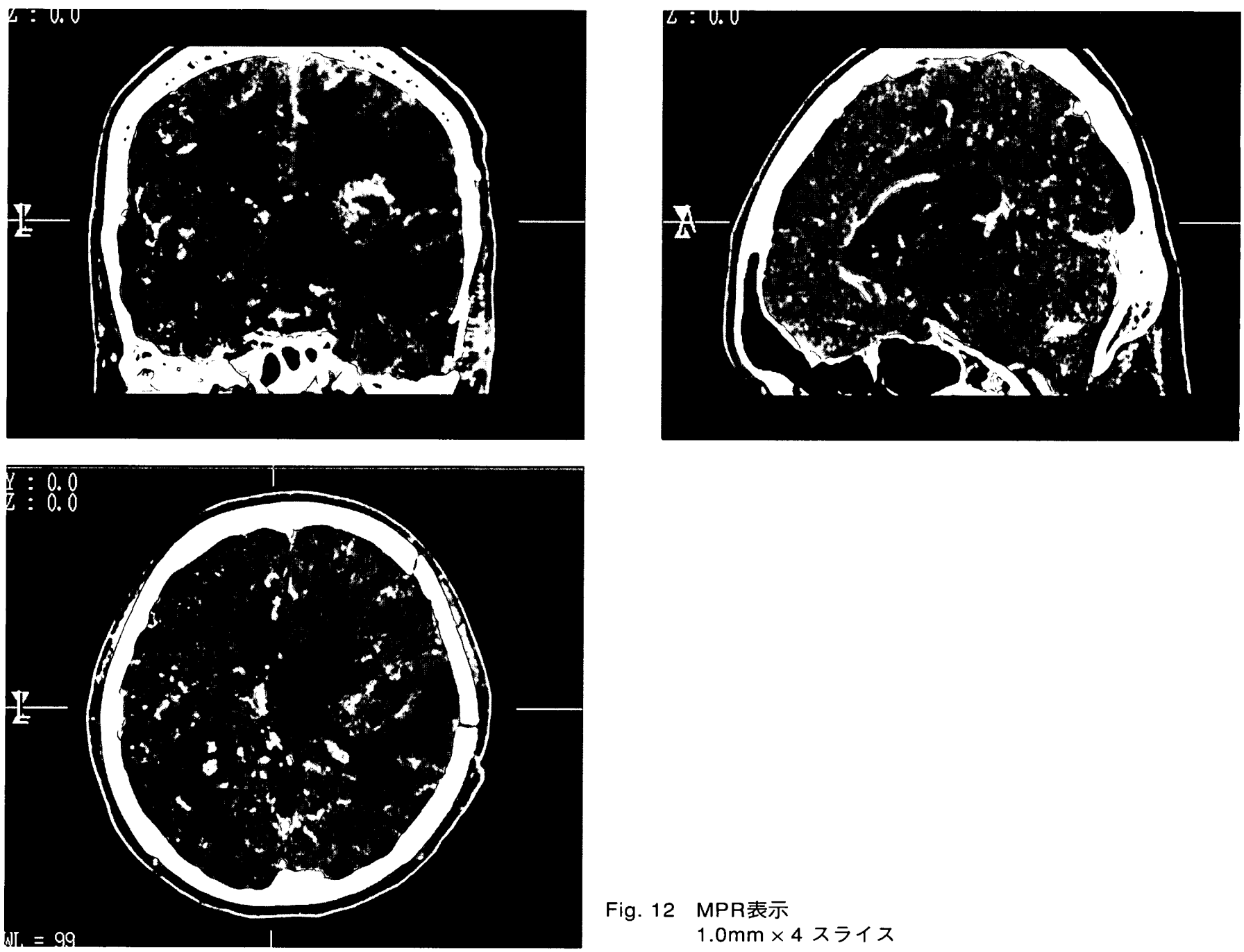

Fig. 12 MPR表示

$1.0 \mathrm{~mm} \times 4$ スライス

いう考えを覆すものである．診断目的によっては軸位 断よりもMPRで他の方向から診たほうが有効な場合 もある。また，たとえば胸部CTにおいて，従来なら 軸位断では多くの画像観察が必要とされた。これを前 額断とすることにより観察画像数は少なくできる．三 次元表示の高精度化も有効であることは言うまでもな い. 従来，三次元表示はオリエンテーション程度のも のとして扱われてきた。 isotropic resolutionにより，

三次元表示を使って診断するという状況にもなってき ている.

\section{4-2 スキャン時間の短縮}

マルチスライスCTのもうひとつの利点としてス キャンの短時間化がある。それは「 1 回の呼吸停止 でスキャンができる」「CT検查が早く終わる」という ことのほかに, CT検査の四次元化の可能性が挙げ られる.Fig. 14にマルチフェイズの造影へリカル スキャンの結果を示す。ヘリカルスキャンで三次元 データが収集できるのは当然であるが，マルチスラ

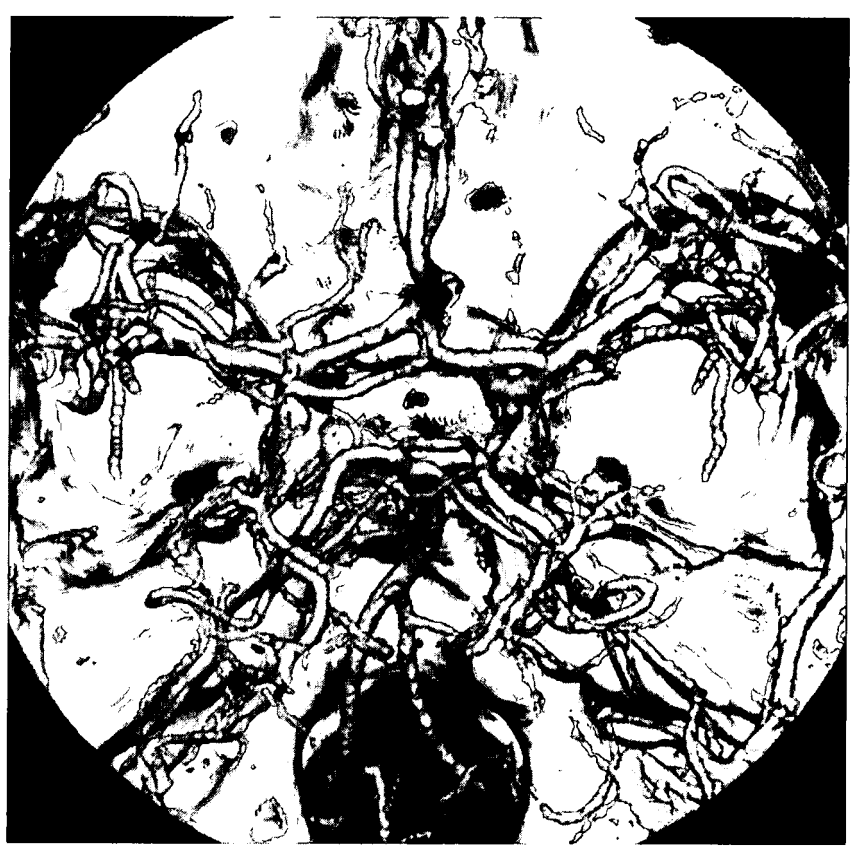

Fig. 13 三次元表示

$0.5 \mathrm{~mm} \times 4$ スライス

イスCTでスキャンが高速化することにより，三次 元デー夕を時間的な連続性をもって収集できるので ある。 


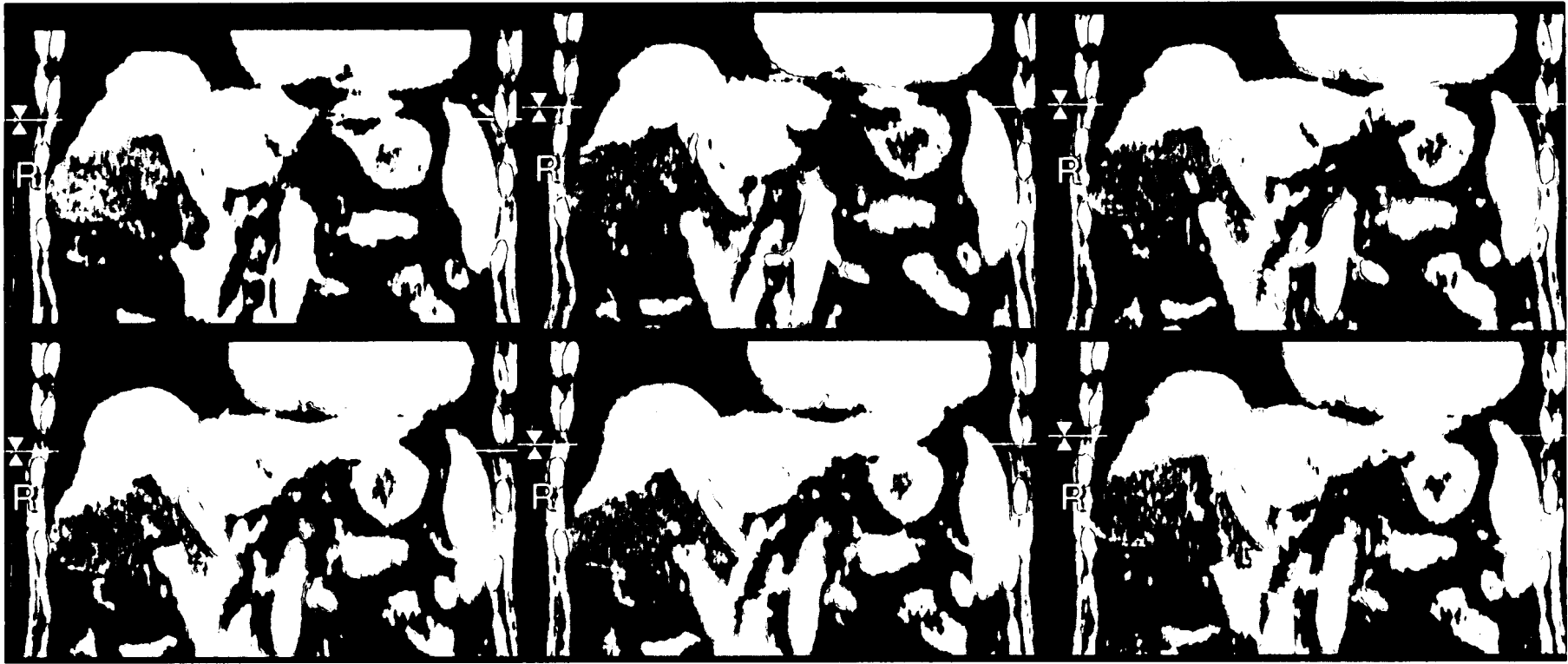

Fig. 14 マルチフェイズ造影ヘリカルスキャン(MPR表示) $5.0 \mathrm{~mm} \times 4$ スライス

\section{5. マルチスライスCTの課題と解決策}

\section{5-1 被曝は?}

前述したように，マルチスライスの登場による臨床 的な利点は多い。しかし，CT装置がX線を利用してい る限り，それによる被曝について注意する必要があ る。薄いスライス厚でスキャンした場合, 薄い一枚一 枚の画像のノイズを低減させようとすれば，管電流を 増加させ, 結局, 被曝を増加させることにもなりかね ない，また，マルチフェイズで造影ヘリカルスキャン を行えば，それだけで被曝も増加する．要は，CT検 查で得られるデータの価值に相当した被曝で検査を終 えることが重要であろう。

\section{5-2 膨大なデータ管理と画像観察}

マルチスライスの出現で問題化したものに，その膨 大なデー夕量がある．従来のノンヘリカルスキャンな らば 1 回のCT検查で数十枚というところであったも のが，ヘリカルスキャンでは百枚程度，マルチスライ スCTでは千枚を超えることもある。これをフィルム に焼き付けていたのでは仕事にならない. CRT診断が 必要になる。CRT診断ならば，リアルタイムMPR, リアルタイム3Dも可能となり，診断の質も向上する ものと考えられる。最近ではHIS (hospital information system), RIS (radiology information system)の構築が 盛んになってきた。マルチスライスCTから発生する 膨大なデー夕に対応したシステムの構築が望まれる。 折角の良質なデー夕を無駄にしないためにも重要なこ とである。

\section{6. マルチスライスCTの次は・.・}

4 DASマルチスライスCTの登場によってCTの開 発，研究は活発になってきている，そこで考えるのが 「4 DASマルチスライスCTの次は？」ということであ る。近末来でいえば, 8 DAS, 16DASのマルチスラ イスCTであろう。この場合，前述した画像再構成に ついての進歩が必要となってくる，そして，その先は といえば，平面的な検出器を有したCT装置である. これができれば完全な四次元CT検査が可能となる. 実際に256DASのCT装置について研究が進んでいる. 従来のノンヘリカルのシングルスライスCTからは想 像もつかなかった「夢のCT装置」が登場しょうとして いる.

次回は「X線CT装置の機器工学(5)ーアーチファク ト-」
1) 瓜谷富三，岡部哲夫：医用放射線科学講座13一放射線機器 工学一。医画薬出版，(1998）.

2) 过岡勝美：CT自由自在.メジカルビュー社，（2001）.
3）森一生，鈴木達郎：アドバンストマルチスライスCT Aquilionの開発. メディカルレビュー, Vol. 25, No. 4, (2001) 